\title{
What is a Nearly zero energy building? Overview, implementation and comparison of definitions
}

Delia D'Agostino ${ }^{\mathrm{a}}$, Livio Mazzarella ${ }^{\mathrm{b}}$

${ }^{a}$ Renewables and Energy Efficiency Unit, Institute for Energy and Transport, Joint Research Centre (JRC) - European Commission, Ispra (VA), Italy, Delia.DAGOSTINO@ec.europa.eu

bEnergy Department, Politecnico di Milano, Via Lambruschini 4, 20156 Milano, Italy, livio.mazzarella@polimi.it

\begin{abstract}
The reduction of energy consumption in buildings is the focus of the European strategy to ensure that future climate and energy targets are reached. This paper focus on the definition of Nearly zero energy buildings (NZEBs) that represent one of the greatest opportunities to increase energy savings in Europe. As this term appears subject to different interpretations, the paper explores the NZEB literature to provide an overview of definitions. The analysis underlines inconsistencies and critical issues among them. The paper also assesses the progress of the NZEB implementation in Europe and it evaluates the main debates arisen around NZEBs. Among these topics, there are:the distinction between energy and primary energy, and between energy sources and energy carriers. Special attention is given in defining primary energy factors for energy carriers produced from renewable energy sources on site, nearby or far. After specifying the role of "plus" buildings, a complementary energy index is proposed to overcome the questioning on the "negative" primary energy index that can be achieved using some of current net ZEB definitions. A proposal for clarifying the meaning of near zero, zero and plus energy buildings is also formulated. The analysis enlightens how, although the attention given to NZEBs increased over the last years, the NZEB topic is still under discussion and not uniformly implemented.
\end{abstract}

Keywords: European energy policy; nearly zero energy buildings (NZEBs); energy efficiency in buildings;

\section{Introduction}

Energy consumption in buildings is a huge concern at European level. Buildings are estimated to account for approximately $40 \%$ of primary energy and $36 \%$ of greenhouse 
emissions [1]. In some Member States this share even exceeds 45\%, making the building sector the largest end-use sector in Europe.

After the 2007 Climate and Energy package of 20\% reduction of buildings primary energy consumption by 2020, 20\% increase of renewable energy production and 20\% decrease of greenhouse gas emissions from 1990 levels, new targets have been introduced by the 2030 Climate \& Energy framework [2]. This package fixes the reduction of greenhouse gas emissions at $40 \%$ from 1990 levels, the share for renewable energy at $27 \%$ and the improvement in energy efficiency at 27\%. Finally, the European Roadmap 2050 aims at reducing greenhouse gas emissions by at least $80 \%$ by 2050 compared to 1990 levels [3]. Figure 1a shows primary energy consumption at European level and the energy efficiency target for 2020.

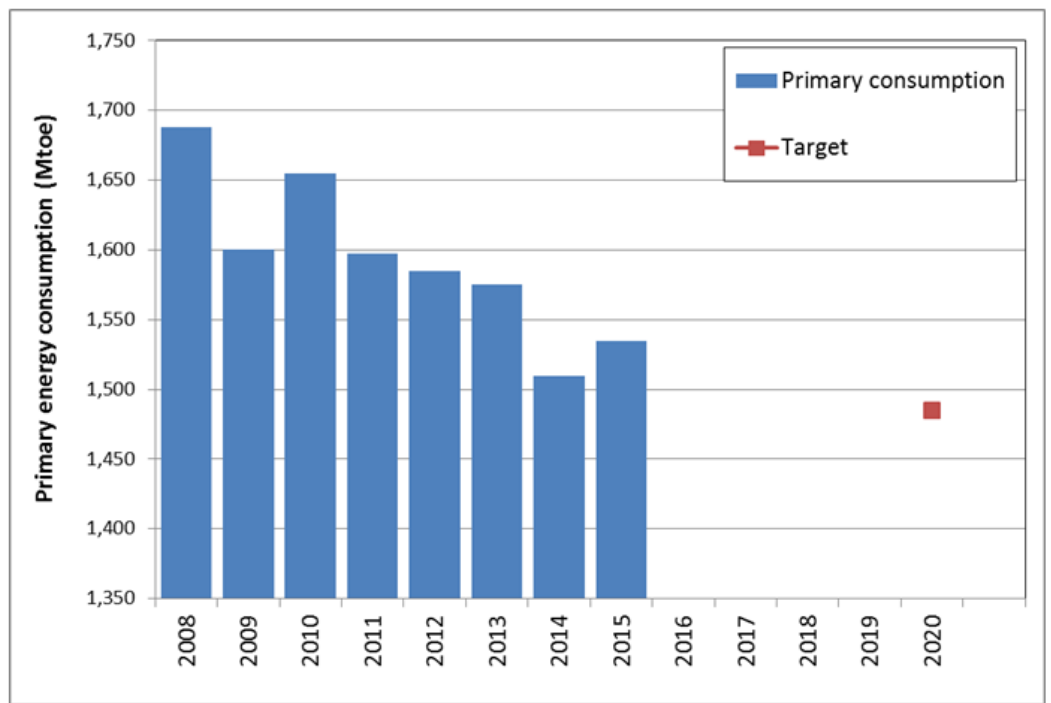

a)

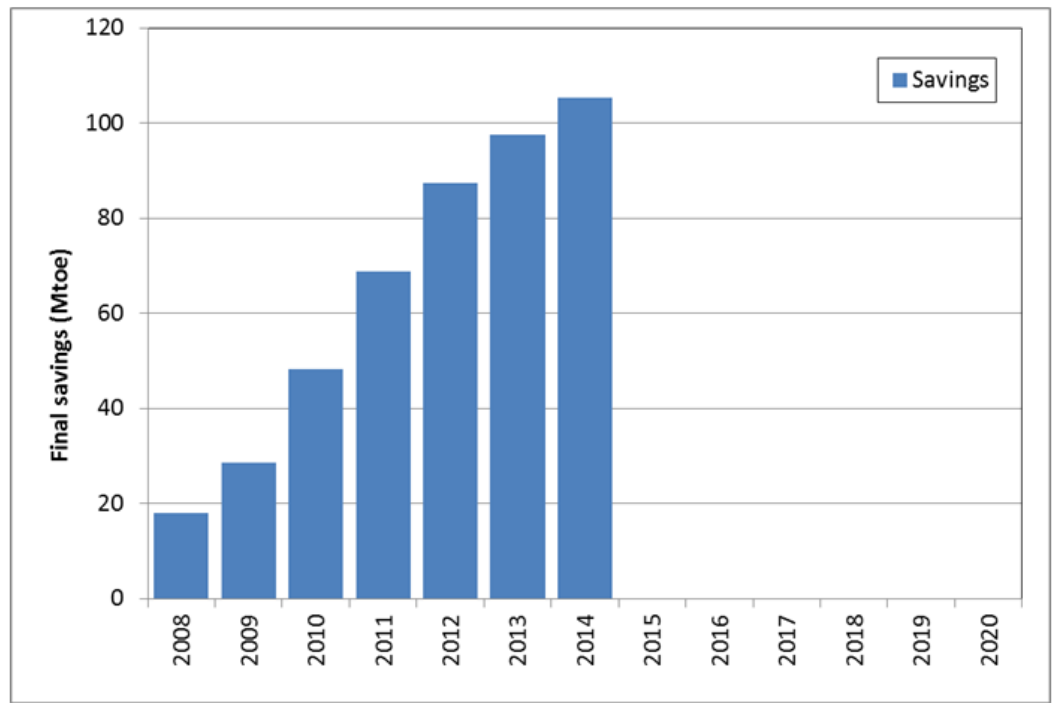

b) 
Figure 1. a) Primary energy consumption at European level and the 2020 target; b) final savings at European level. Source: [4][5].

New policies have introduced technical and regulatory measures to promote a more rational use of energy over the last decade. Their implementation generated an increase of savings in European buildings (Figure 1b). One key measure aimed at reducing energy consumption in buildings is the introduction of Nearly zero energy buildings (NZEBs) as the new building target [6].

After summarising the trends of energy consumption in buildings, this paper clarifies the meaning of the NZEBs and other launched definitions. An update of the implementation of NZEBs in Europe is then given. This analysis is reported in Section 2 and it establishes the European Union (EU) progress in comparison with a previous assessment [7]. Afterwards, a discussion is open on the main issues around the reported definitions (Section 3). Section 3.1 discusses the key aspects of the United States (US) Department of Energy (DOE) Zero Energy Buildings (ZEB) and positive energy buildings definitions. Section 3.2 reports a discussion around NZEBs definitions. Critical issues are then presented in Section 3.3 in relation to primary energy conversion factors. An alternative to the Net ZEB to account for the renewable energy export is finally described in Section 3.4.

\subsection{Energy consumption in buildings}

In Europe there are about 25 billion $\mathrm{m}^{2}$ of building useful floor space. The annual new buildings growth rate is assessed at around 1\% in the European residential sector [8]. The decrease in the rate of new constructions in the last decade is mainly due to financial crisis of the construction sector.

Data on the total building stock in European Member States is reported in Figure 2 together with the number of new dwellings divided per typology. 


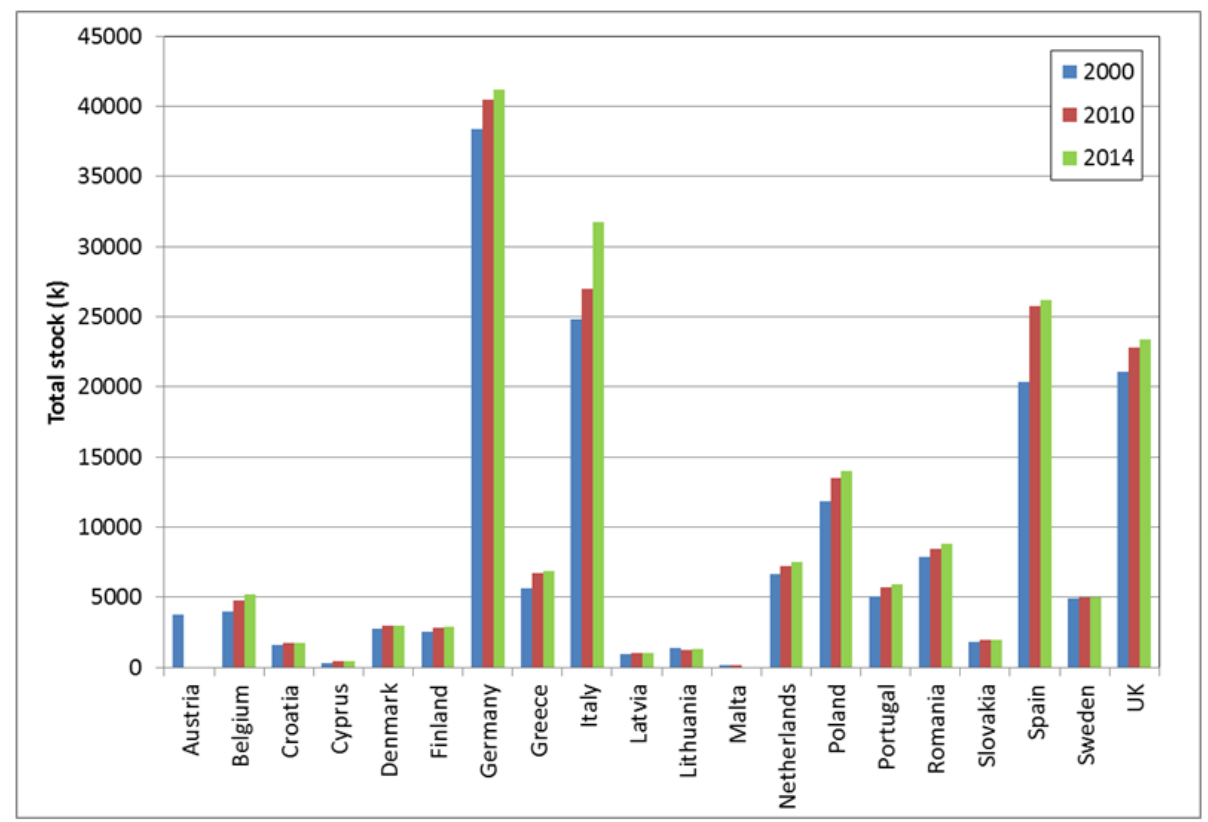

a)

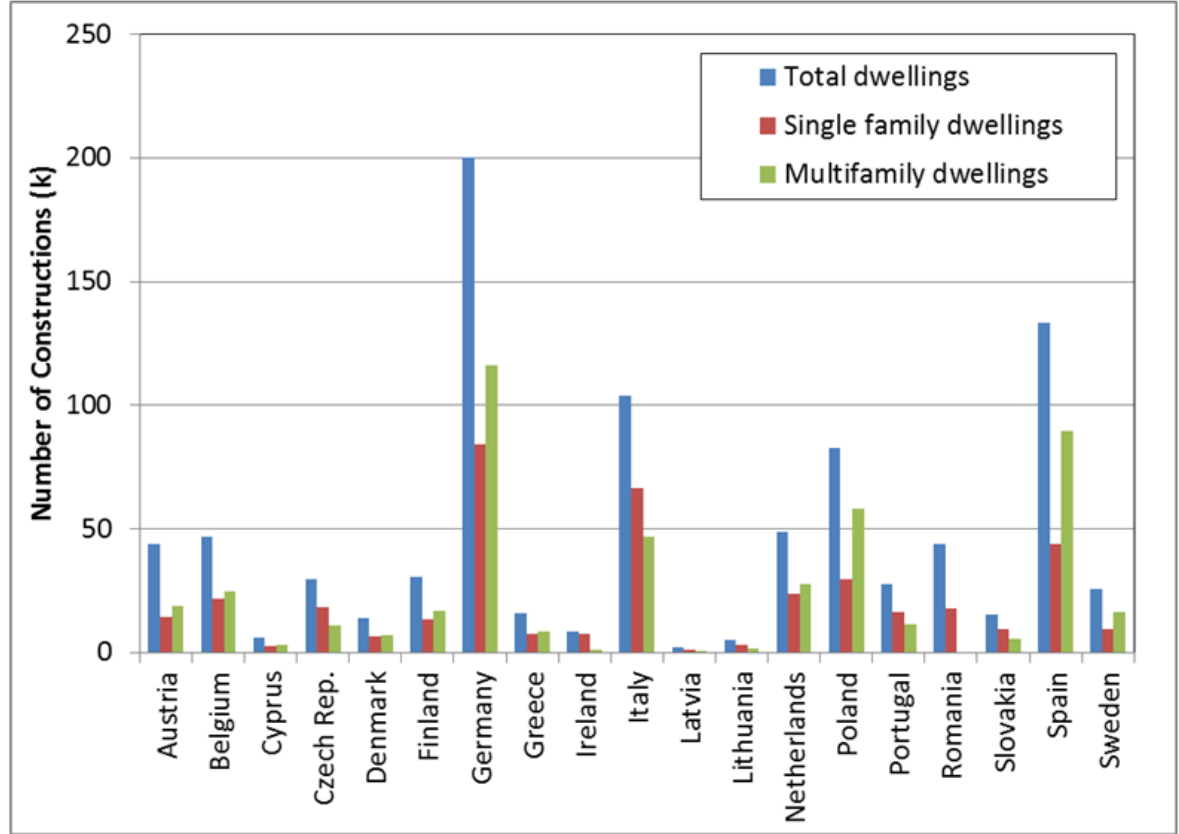

b)

Figure 2. a) Total stock in European Member States, b) New dwellings constructions in 2012. Source: elaborated from [4].

Data on energy consumption of the existing stock show that the largest energy saving potential is associated with the older building stock characterized by a lack of building envelope insulation. A comparison of energy consumption for different end-uses between Europe and other countries is given in Figure 3. 


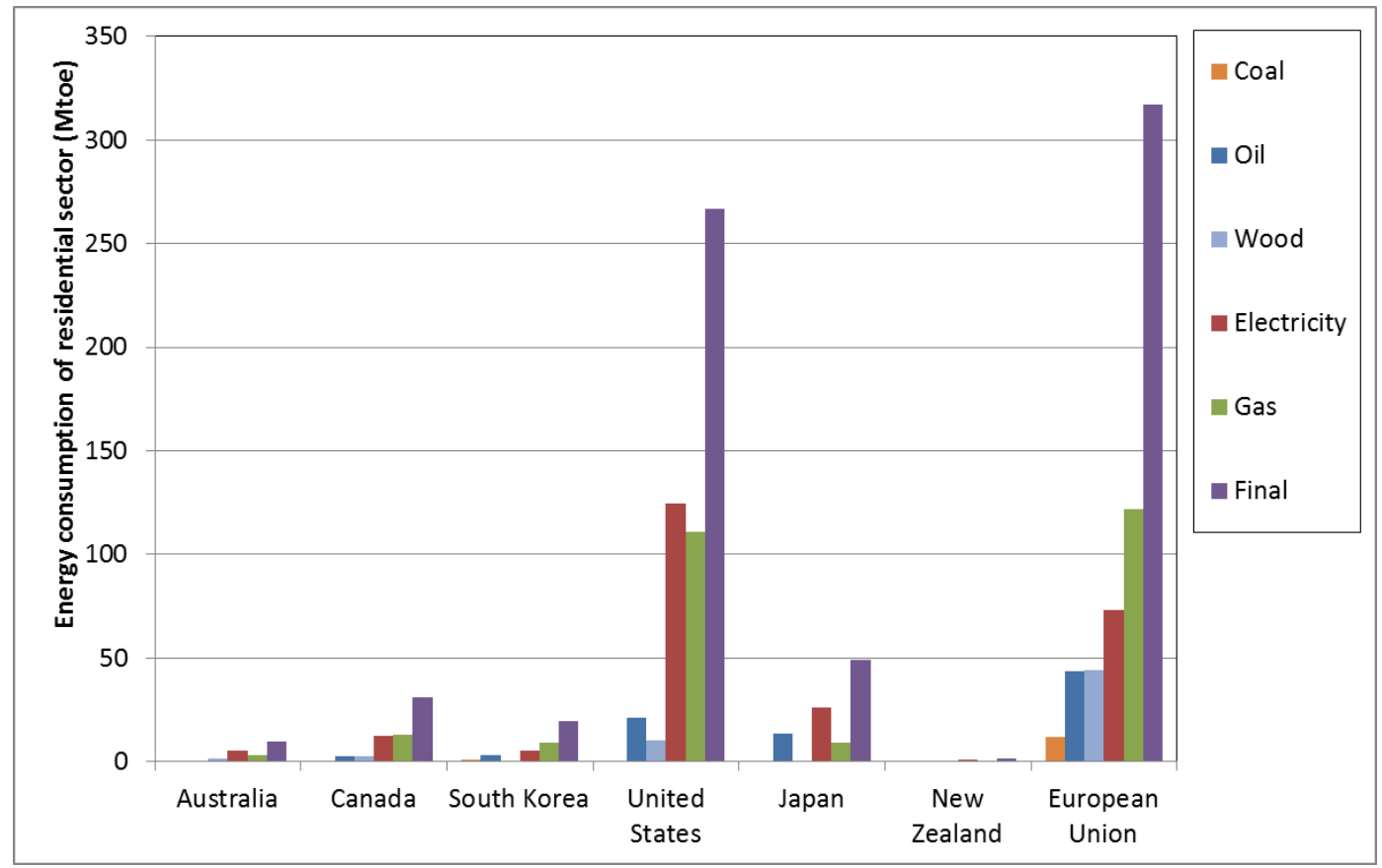

Figure 3. Coil, oil, wood, electricity, gas and final consumption for the residential sector in different nations (year 2012). Source: elaborated from [4].

As shown in Figure 3, energy consumption is high in Europe in comparison to other countries. In Europe, the predominant energy end-use is space heating which is responsible for about $70 \%$ of dwelling consumption. Fossil fuels represent the $37 \%$ of space heating consumption in the residential sector. Heating consumes a great part of the total energy consumption also in Australia (62\%) and the US (43\%).

Non-residential buildings account on average for $25 \%$ energy consumption of the total European building stock, representing a heterogeneous sector compared with the residential. Figure 4 reports the share of residential and non-residential buildings in European final energy consumption. 


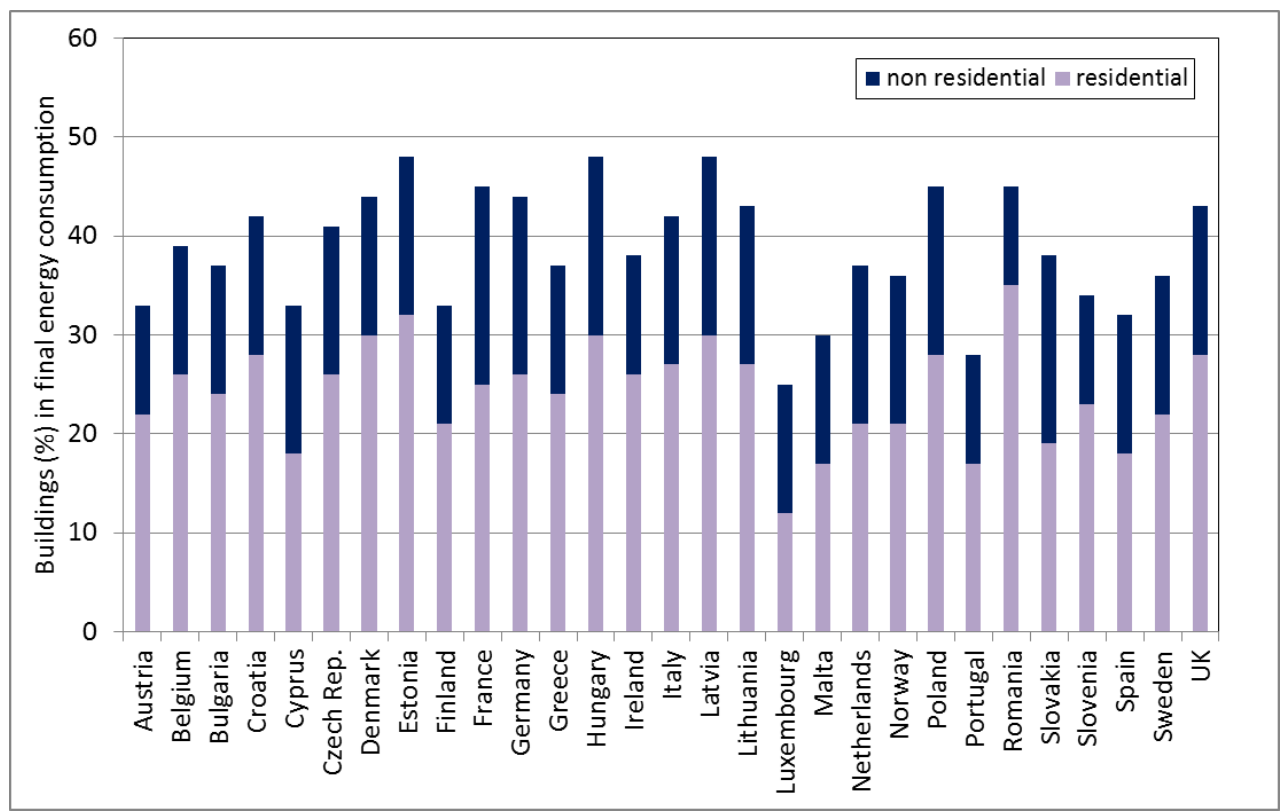

Figure 4. Share of buildings in final energy consumption (2012). Source: elaborated from [5].

The average specific energy consumption is on average $280 \mathrm{kWh} / \mathrm{m}^{2}$, which is at least $40 \%$ greater than the equivalent value for the residential sector [9]. Over the last decade, electricity consumption has increased between 2008 and 2012 mainly due to a growing number of new appliances, IT devices, and air conditioning [10] [11].

Figure 5 reports electricity, gas, oil and final energy consumption in the residential sector in different European Member States. 


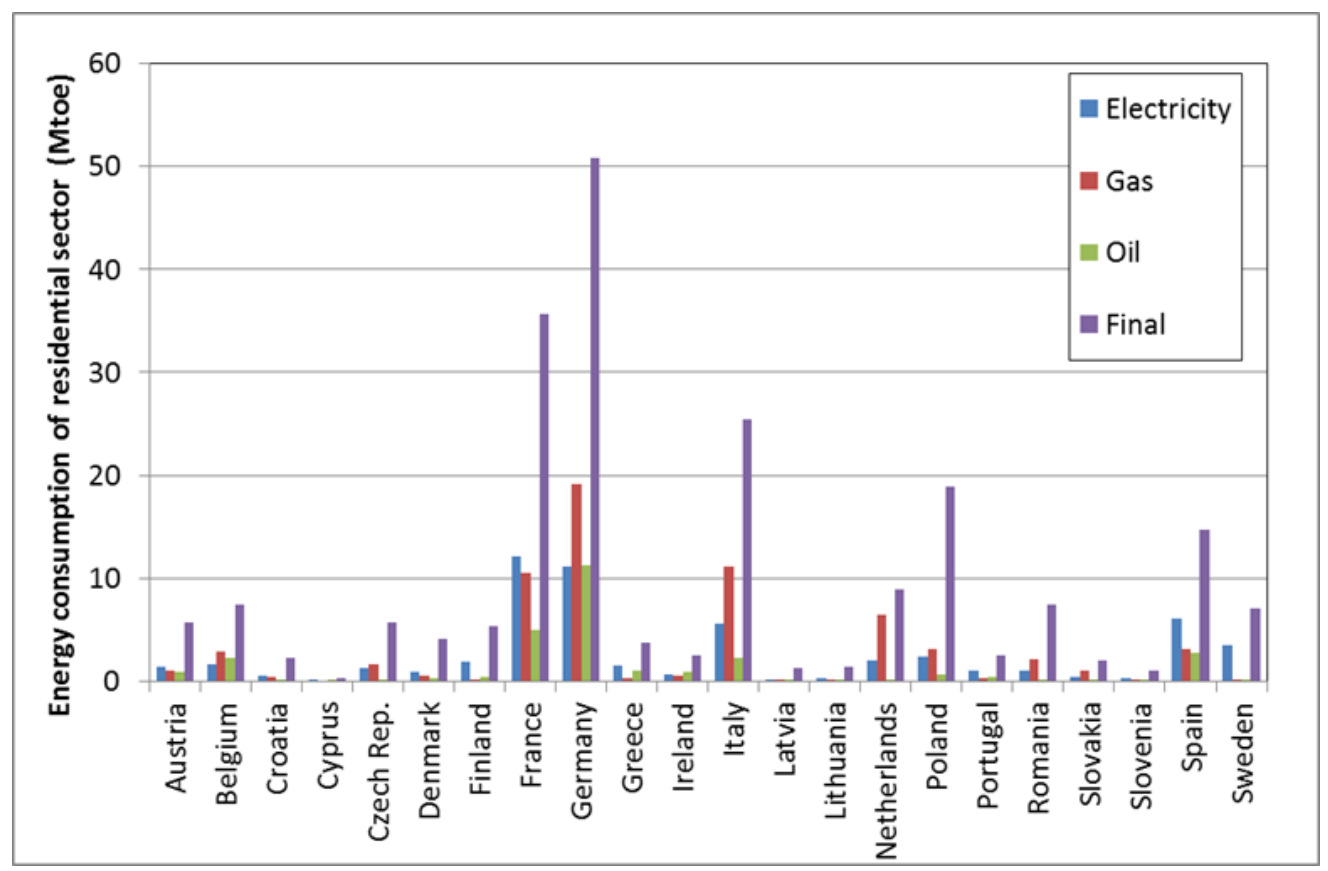

Figure 5. Electricity, gas, oil and final energy consumption in the residential sector in Europe (year 2014). Source: elaborated from [2].

Germany, France, Italy, Poland and Spain are among the countries with higher energy consumption. In 2008 the residential consumption per dwelling was 1.58 toe while it was is 1.21 toe per dwelling in 2014 [12][13]. Electricity consumption per household has been decreasing in most countries since 2008 thanks to the diffusion of efficient appliances, compact Fluorescent Lights and Light Emitting Diode. Without energy efficiency improvements, the energy consumption of households would have been 60 Mtoe higher in 2012 considering the increasing number of dwellings and appliances.

\subsection{EU NZEBs}

The European Union (EU) set up a policy framework focused on reducing energy consumption and obtaining important savings from buildings. One important policy action is the Energy Performance of Buildings Directive recast (EPBD recast, Directive 2010/31/EC) [14]. Other Directives aimed at the improvement of buildings energy performance are the Energy Efficiency Directive (EED) (EU, 2012/27/EU) and the Renewable Energy Directive (RED) (EU, 2009/28/EU) [15] [16].

According to the EPBD recast, nearly zero energy buildings (NZEBs) represent the building target from 2018 onwards [17]. New buildings occupied by public authorities and 
properties have to be NZEBs by December 31, 2018 and all new buildings by December 31, 2020.

A NZEBs is defined as a building with a very high energy performance, as determined in accordance with Annex I. The nearly zero or very low amount of energy required should be covered to a very significant extent by energy from renewable sources produced on-site or nearby. The EPBD states that Member States shall detail the NZEB definition, reflecting national, regional or local conditions, and including a numerical indicator of primary energy use expressed in $\mathrm{kWh} / \mathrm{m}^{2}$ per year. Primary energy factors used for the determination of the primary energy use may be based on national or regional yearly average values and may take into account relevant European standards.

Quantitative definitions of "very high energy performance” and "a very significant extent by energy from renewable sources” have to be given by Member States. Furthermore, the primary energy to be used in the numerical performance indicator (total, non-renewable or renewable) and the meaning of "nearby" are also subject to definition.

Another important EPBD recast provision relates the introduction of cost-optimality. A comparative methodology framework to derive cost-optimal levels of minimum energy performance requirements for buildings and building elements is given in the Delegated Regulation No 244/2012 supplementing the EPBD recast [18] [19]. The cost-optimal level is defined as "the energy performance level which leads to the lowest cost during the estimated economic lifecycle”. The methodology involves the definition of reference buildings and the application of energy efficiency measures to reduce primary energy consumption and address the choice of the most economically advantageous solutions [20] [21] [22].

Several studies have shown how a heterogeneous situation characterizes Europe in relation to building and climate types [23][24][25]. Consequently, different cost-optimal levels and packages of energy efficient measures can be found [26].

The cost-optimal concept is strictly connected to NZEBs as cost-optimality sets the minimum level of ambition for both building renovation and new buildings (Figure 6). The European Commission Recommendation on Guidelines for the promotion of NZEBs [17] states that there cannot be a single performance level for NZEBs across Europe. Flexibility is needed to account for the impact of climatic conditions on heating and cooling needs and on the cost-effectiveness of packages of energy efficiency and renewable energy sources measures. 


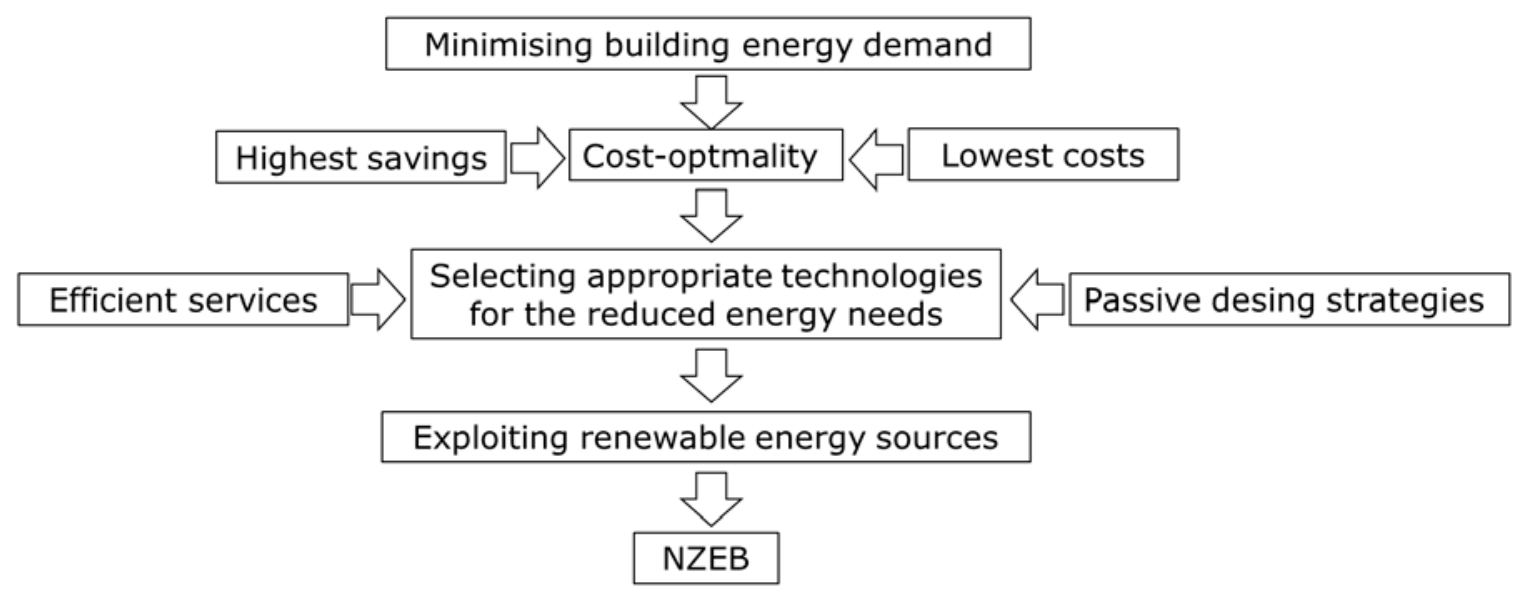

Figure 6. Concept of NZEBs.

Apart from the NZEB concept defined in the EPBD, other terms and definitions are appearing to qualify new buildings placed on the market. But, despite the large debate over the last decade, there is still no common general agreement on the technical meaning of such terms. These will be analysed in the next sections starting with the US definition.

\subsection{US DOE ZEB}

An important definition around zero energy buildings (ZEBs) is that of the US Department of Energy (DOE). A ZEB building is:“An energy-efficient building where, on a source energy basis, the actual annual delivered energy is less than or equal to the on-site renewable exported energy” [28].

In this definition:

- the source energy is the site (building) energy, plus the energy consumed in the extraction, processing and transport of primary fuels such as coal, oil and natural gas; energy losses in thermal combustion and in power generation plants; and energy losses in transmission and distribution to the building site.

- building energy is the energy consumed at the building site as measured at the site boundary. At minimum, this includes heating, cooling, ventilation, domestic hot water, indoor and outdoor lighting, plug loads, process energy, elevators and conveying systems, and intra-building transportation systems.

To accommodate the collections of buildings where renewable energy resources were shared, three more definitions were added: Zero Energy Campus (ZEC), Zero Energy Portfolio (ZEP), Zero Energy Community (ZECo). These definitions are obtained from the 
ZEB definition just substituting the term building respectively with campus (ZEC), portfolio (ZEP) and community (ZECo), where:

- campus is a group of building sites in a specific location that contains renewable energy systems owned by an institution;

- portfolio is a collection of building sites that contains renewable energy production systems owned/leased by a single entity;

- community is a group of building sites in a specific location that contains renewable energy systems.

To assess the energy performance, delivered $\left(E_{d e l}\right)$ and exported $\left(E_{\text {exp }}\right)$ energies through the site boundary for each energy type have to be measured or calculated. The source energy is then derived using source energy conversion factors $\left(r_{i}\right)$ from ASHRAE Standard 105. Given the same source energy conversion factor for the exported renewable electricity and the delivered grid non-renewable electricity, the on-site renewable exported energy is "the delivered energy to appropriately credit its displacement of delivered electricity”. The ZEB site boundary could be around the building footprint, if the on-site renewable energy is located within the building site. Otherwise it is around it, if a part of the on-site renewable energy is on-site, but not within the building footprint. The ZEC site boundary allows the building sites on a campus to be aggregated, so that the combined on-site renewable energy could offset the building energy derived from the buildings on the campus. The ZECo or ZEP site boundary would allow a group of project sites at different locations to be aggregated. In this way, the resulting on-site renewable energy could offset the combined building energy from the aggregated project sites.

There is instead no definition explaining what an energy-efficient building is, and a limitation on the ZEB label use is the following: "the designation of Zero Energy Building (ZEB) should be used only for buildings that have demonstrated through actual annual measurements that the delivered energy is less than or equal to the on-site renewable exported energy."

\subsection{Overview of other definitions}

Different terms and building categories have been launched in recent years after the NZEB definition given in the EPBD. This testifies how the topic has been widely analysed and debated, but it is still subject to discussion at international level in relation to the technical meaning of these terms. As shown in Table 1, among them, there are: zero, net and 
plus buildings. Many of these building categories have been placed on the market to underline their quality as environmental friendly buildings mainly driven by technical and/or commercial interests [29].

Table 1: Main terms launched around zero energy buildings.

\begin{tabular}{|c|c|c|c|}
\hline Acronym & Meaning & Characteristics & Reference \\
\hline NZEB & $\begin{array}{l}\text { Nearly Zero Energy } \\
\text { Building }\end{array}$ & $\begin{array}{l}\text { Very high energy performant building } \\
\text { with a very low amount of energy } \\
\text { required covered to a very significant } \\
\text { extent by energy from on-site or nearby } \\
\text { renewable sources }\end{array}$ & [15] \\
\hline Net ZEB & $\begin{array}{l}\text { Net Zero Energy } \\
\text { Building }\end{array}$ & $\begin{array}{l}\text { Yearly energy neutral building that } \\
\text { delivers as much energy to the grid as it } \\
\text { draws back }\end{array}$ & [30] \\
\hline ZEB & $\begin{array}{ll}\text { Zero } & \text { Energy } \\
\text { Building } & \\
\end{array}$ & $\begin{array}{l}\text { Zero energy consumed by a building in } \\
\text { its day-to day operation }\end{array}$ & [31] \\
\hline ZEB & $\begin{array}{ll}\text { Zero } & \text { Emission } \\
\text { Building } & \\
\end{array}$ & $\begin{array}{l}\text { Zero carbon emissions released into the } \\
\text { environment }\end{array}$ & [31] \\
\hline NZSoEB & $\begin{array}{l}\text { Net Zero Source Energy } \\
\text { Building }\end{array}$ & $\begin{array}{l}\text { A building that produces at its location } \\
\text { as much energy as it uses in a year, } \\
\text { when accounted for at the source }\end{array}$ & [32] \\
\hline NZSiEB & $\begin{array}{l}\text { Net Zero Site Energy } \\
\text { Building }\end{array}$ & $\begin{array}{l}\text { A building that produces at its location } \\
\text { as much energy as it uses in a year, } \\
\text { when accounted for at the building }\end{array}$ & [32] \\
\hline NZEC & $\begin{array}{l}\text { Net Zero Energy Cost } \\
\text { Building }\end{array}$ & $\begin{array}{l}\text { The amount of money the owner pays } \\
\text { for the energy consumed is balanced by } \\
\text { the money the owner receives for the } \\
\text { energy delivered to the grid over a year }\end{array}$ & [32] \\
\hline nNZEB & $\begin{array}{l}\text { Nearly Net } \\
\text { Energy Building }\end{array}$ & $\begin{array}{l}\text { A building with a national cost optimal } \\
\text { energy use greater than zero primary } \\
\text { energy }\end{array}$ & [37] \\
\hline $\begin{array}{l}\text { Autonomous } \\
\text { ZEB }\end{array}$ & $\begin{array}{l}\text { Autonomous Zero } \\
\text { Energy Building }\end{array}$ & $\begin{array}{l}\text { Stand-alone building that supplies its } \\
\text { own energy needs }\end{array}$ & {$[38]$} \\
\hline$+\mathrm{ZEB}$ & $\begin{array}{ll}\text { Energy } & \text { Plus } \\
\text { Building } & \end{array}$ & $\begin{array}{l}\text { A building that produces more energy } \\
\text { from renewables than it imports over a } \\
\text { year }\end{array}$ & [38] \\
\hline PV-ZEB & $\begin{array}{l}\text { Photovoltaic Zero } \\
\text { Energy Building }\end{array}$ & $\begin{array}{l}\text { A building with a low electricity energy } \\
\text { demand and a photovoltaic system (PV) }\end{array}$ & $\begin{array}{l}\text { Error! } \\
\text { Reference } \\
\text { source not } \\
\text { found. }\end{array}$ \\
\hline Wind-ZEB & $\begin{array}{l}\text { Wind Zero Energy } \\
\text { Building }\end{array}$ & $\begin{array}{l}\text { A building with a low electricity energy } \\
\text { demand an on-site wind turbine }\end{array}$ & $\begin{array}{l}\text { Error! } \\
\text { Reference } \\
\text { source not } \\
\text { found. }\end{array}$ \\
\hline $\begin{array}{l}\text { PV-Solar } \\
\text { thermal-heat } \\
\text { pump ZEB }\end{array}$ & $\begin{array}{lr}\text { Photovoltaic } & \text { Solar } \\
\text { thermal heat pump } \\
\text { Zero }\end{array}$ & $\begin{array}{l}\text { A building with a heat and electricity } \\
\text { demand, a PV system in combination } \\
\text { with solar thermal collectors, heat }\end{array}$ & $\begin{array}{l}\text { Error! } \\
\text { Reference } \\
\text { source not }\end{array}$ \\
\hline
\end{tabular}




\begin{tabular}{|l|l|l|l|}
\hline & Building & pumps and heat storage & found. \\
\hline $\begin{array}{l}\text { Wind-Solar } \\
\text { thermal-heat } \\
\text { pump ZEB }\end{array}$ & $\begin{array}{l}\text { Wind Solar thermal pump Zero } \\
\text { heat building with a low heat and }\end{array}$ & $\begin{array}{l}\text { Error! } \\
\text { electricity demand and a wind turbine in } \\
\text { Energy Building } \\
\text { combination with a solar thermal } \\
\text { collector, a heat pump and heat storage }\end{array}$ & $\begin{array}{l}\text { source not } \\
\text { found. }\end{array}$ \\
\hline
\end{tabular}

Zero Energy Building (ZEB) is a terminology that has been overexploited, often describing very different building typologies, and the acronyms, ZEB, can be used to address very different targets, for instance, it was applied to both energy and carbon emissions: ZEB was referred to a Zero Energy Building, as defined in [30], and Zero Emission Building, as defined in [31]. The first is referred to the net energy (not primary energy) delivered to a building in its day-to day operation, the second to the carbon emissions released into the environment as a result of its operation.

However, if the meaning of "zero" is unambiguously defined, it is not as immediate to specify what the other terms mean. A first attempt to come up with a more clear and useful definition of ZEB was done by Torcellini et al. in 2006 [32]. The authors also produced four different (sub)definitions: Zero Net Energy Building (ZNEB), Net Zero Site Energy Building (NZSiEB), Net Zero Source Energy Building (NZSoEB), Net Zero Energy Cost Building (NZEC). All these definitions have been introduced to account for different boundaries and metrics, which can be in turn more appropriate to the goals of designers, owners, and organizations. ASHRAE, in its vision for 2020 [33], came up with a single definition choosing the NZSiEB as the type of building which can be simply named NZEB. Thus, the term ZEB was left aside to use the NZEB term, which stresses that such building can have a net zero energy balance on the site via two-way energy exchange with the grid.

On the same route was the work done by the International Energy Agency (IEA), Solar Heating and Cooling (SHC) Task 40, and the Energy Conservation in Buildings and Community systems (ECBCS) Annex 52 which is titled Towards Net Zero Energy Solar Buildings. Starting with a review of definitions on ZEBs in 2011, [34] [35], they came up with a consistent definition framework for NZEBs in 2012 [36], stressing that the term Net ZEB indicates a building connected to the grid, which balances imported weighted energy with exported weighted energy to the grid. They also introduced the concept of Nearly Net Energy Building (nNZEB) and Net Plus Energy Building (NPEB) [37], giving only an intuitive graphical definition of them.

Another definition differentiates Autonomous ZEB from Net ZEB [38]. An autonomous ZEB is not connected to the energy grid. These stand-alone buildings supply their own 
energy needs and are able to store energy for night-time or winter-time use. On the contrary, a Net ZEB is a yearly energy neutral building that delivers as much energy to the supply energy grid as it draws back. It must be noted the in this context energy grid is not only the electrical grid but the whole regional energy system (i.e. delivered energy carriers as electricity, gas, oil, heat from district heating system, etc.). An Energy Plus Building (+ZEB) produces more energy from renewable energy sources (RES) than it imports over a year. However, even if a common customer sense of "positive" means greater than zero, it should be clear that a positive building cannot create energy, violating the energy conservation principle. Buildings using less delivered energy than exported on-site renewable energy would have a negative source energy, just because the import/export weighted balance is made with weighted energy carriers that cross the building boundary and does not account for the amount of source energy extracted from the on-site renewable energy sources (solar radiation, wind energy, etc.) as energy carriers crossing the boundary. Among other definitions, there are: Positive Energy Buildings (PEB) in Denmark and France, Climate Neutral Buildings (CNB) in Germany and Zero Carbon Buildings (ZCB) in the United Kingdom.

Other different terms have been listed depending on boundaries and the metrics [39]. A Net Zero Site Energy building is as a building that produces at its location at least the amount of energy that it uses. A hierarchy of renewable supply options has been proposed. This encourages the reduction of site energy use through low-energy technologies and the use of renewables available within the building footprint or at the site.

Four types of ZEBs can be distinguished in reference to the energy demand and the installed renewables [31]. A PV-ZEB is a building with a relatively low electricity demand and a photovoltaic system (PV), while a Wind-ZEB has a relatively low electricity demand and a small on-site wind turbine. A PV-Solar thermal-heat pump ZEB is characterized by a low heat and electricity demand as well as by a PV installation in combination with solar thermal collectors, heat pumps and heat storage. A Wind-Solar thermal-heat pump ZEB has a low heat and electricity demand and a wind turbine in combination with a solar thermal collector, a heat pump and heat storage.

In 2014, the US DOE Building Technologies Office together with the National Institute of Building Sciences (NIBS) established definitions and guidelines for zero energy buildings, with the goal of achieving a large diffusion in the industry [28]. As according to the DOE Zero Energy Ready Homes program, the term "net” was confusing to consumers, DOE and NIBS selected the term Zero Energy Building (ZEB) to indicate instead NZEBs. However, 
they recognise that the terms Net Zero Energy (NZE) and Zero Net Energy (ZNE) are in wide use and convey the same meaning as Zero Energy.

To support the definition of a common European framework, the European Committee for Standardization (CEN) reviewed its technical standards [40]. The resulting overarching standard, rEN ISO/DIS 52000-1:2017, is addressing the NZEB definition in Annex H, as a methodological proposal [41].

The European Federation of HVAC National Associations (REHVA) started a task force on Nearly Zero Energy Buildings, which has published a comprehensive technical definition of NZEBs as a compromise among different opinions [42] [43] [44]. This survey, limited to the main literature sources on ZEB, NZEB and nZEB, clearly shows two principal issues: a) the different perspective and then characteristics of such buildings in the market-oriented US DOE approach and in the "by law" European approach; b) the different meaning of near and positive attributes if a different zero reference is chosen, i.e. NZEB or off-grid or autonomous or self-sustainable building.

\section{Implementation of NZBEs definitions in Europe}

The implementation of NZEBs definitions in Europe is based on National Plans and the Commission report of 2016. The analysis updates the progress compared to the previous assessment of 2015. Different source of information has been considered, including Commission templates, the EPBD Concerted Action (CA), Energy Efficiency Action Plans (NEEAP), and National Codes [45].

As seen in Section 1.2, the EPBD NZEB definition leaves Member States the freedom to define some aspects around NZEBs. Among them there are: building category, typology, physical boundary, type and period of balance, included energy uses, renewable energy sources (RES), metric, normalization, and conversion factors.

Figure 7 reports building typology (new/retrofit), building classification (public/private), balance type, and physical boundary as selected by Member States in the NZEB definitions. 

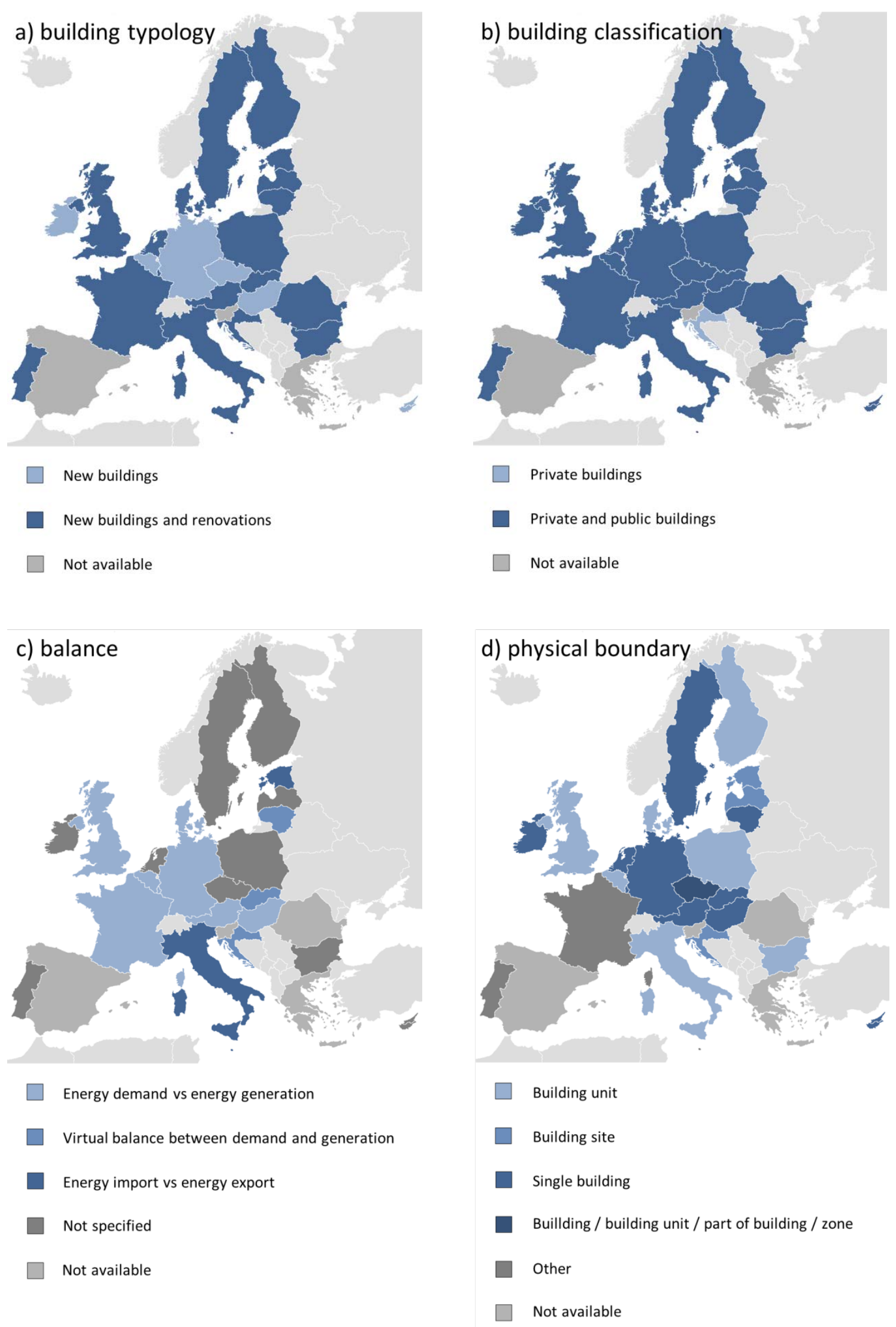

Figure 7. a) Building typology; b) Building classification; c) Balance; d) Physical boundary in European NZEBs definitions. Source [17]. 
The majority of Member States include new and retrofit, private and public buildings in the NZEB definition (Figure 7a and 7b). Energy demand against energy generation is the most selected balance calculation (Figure 6c), but many Member States have not yet established a methodology. In relation to physical boundary, the most selected option is single building or building unit (Figure 7d).

Figure 8 shows balance periods, normalization, metric and time dependent weighting as selected in NZEB definitions.
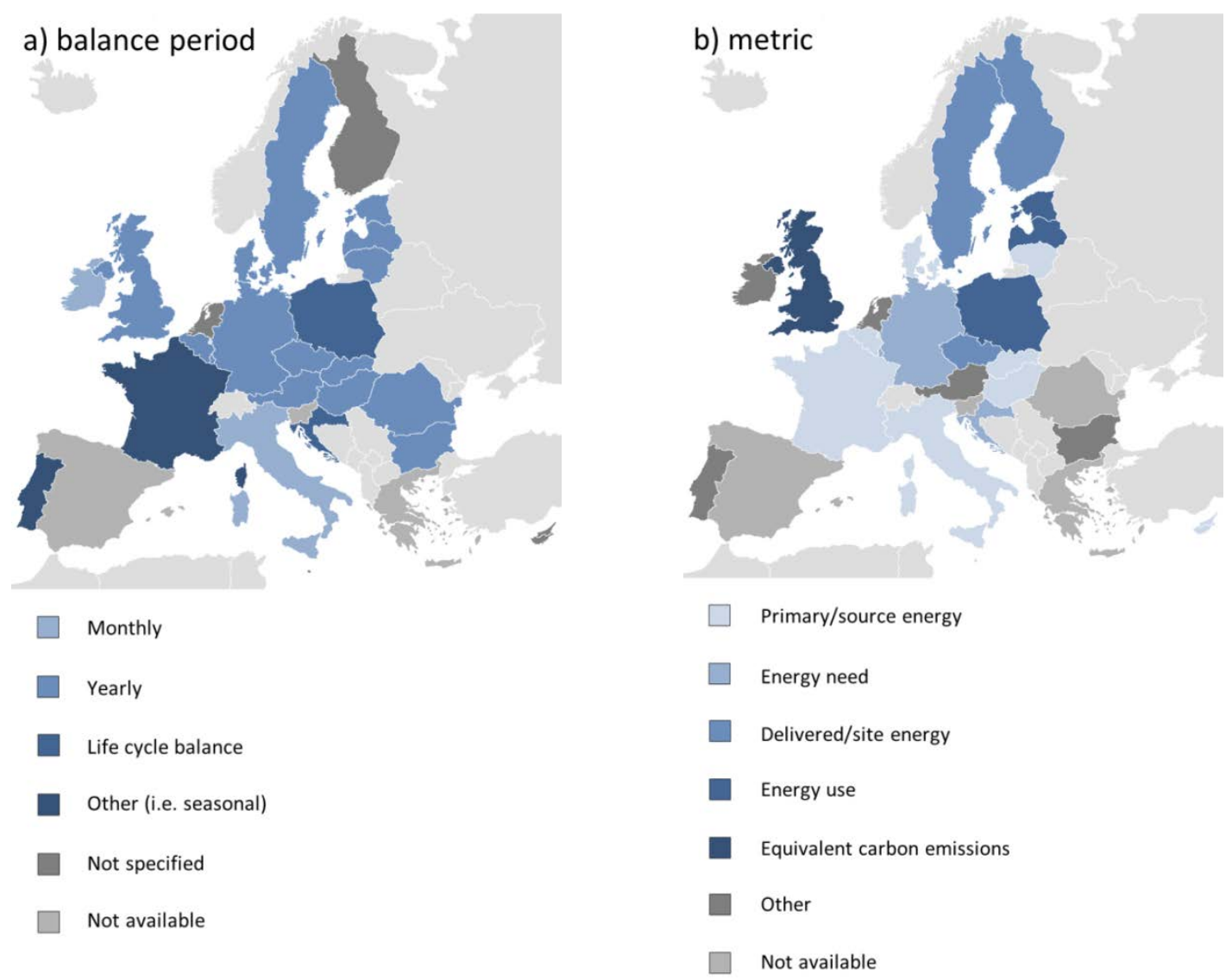

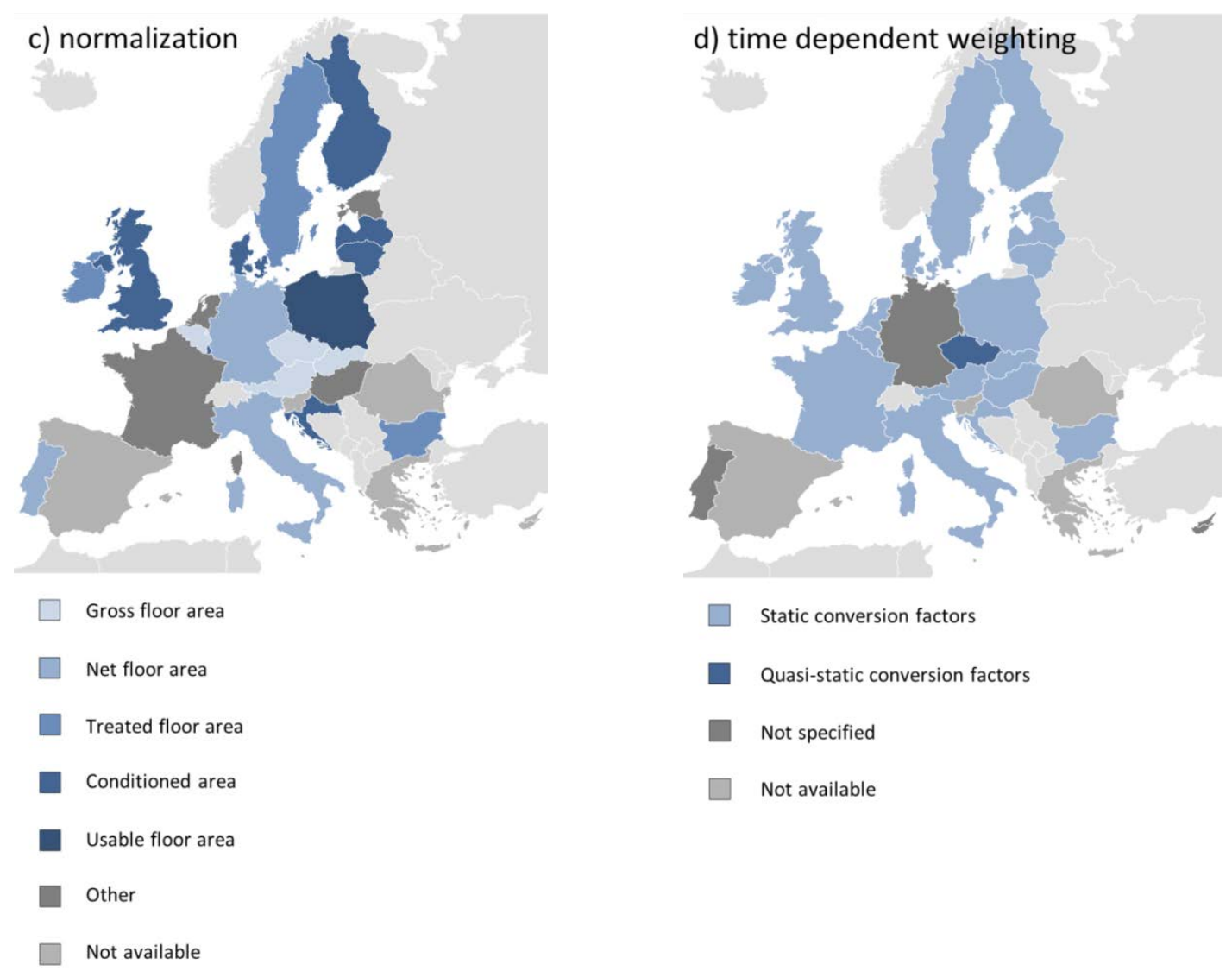

Figure 8. a) Balance period; b) metric; c) normalization; d) time dependent weighting in European NZEBs definitions. Source [17].

Most Member States indicate a balance of a year (Figure 8a), primary/source energy (renewable part not included), and delivered/site energy (Figure 8b). A few countries refer to energy need or energy use, and only one equivalent to carbon emissions. Normalization can vary a lot across Europe (Figure 8c). It can be conditioned area, while other options are equally distributed among the possible alternatives, with some Members State preferring gross floor area, and other treated floor area, and net floor area. Many countries consider static conversion factors as time dependent weightings (Figure 8d).

A numeric indicator of energy performance expressed as primary energy in $\mathrm{kWh} / \mathrm{m}^{2} / \mathrm{y}$ use has been also given by European countries. Table 2 collects information based on not homogeneous calculation methods and general conditions, therefore widely varying computational results can be obtained for primary energy.

Table 2. Energy requirements defined by EU Member States for NZEB levels (PE: primary energy, n/a: not available).

\begin{tabular}{ccccc}
\hline \multirow{3}{*}{ Country } & \multicolumn{2}{c}{ Residential Buildings } & \multicolumn{2}{c}{ Non-Residential Buildings } \\
\cline { 2 - 4 } & \multicolumn{2}{c}{$(\mathrm{kWh} / \mathrm{m} 2 / \mathrm{y}$ or Energy Class $)$} & \multicolumn{2}{c}{$(\mathrm{kWh} / \mathrm{m} 2 / \mathrm{y}$ or Energy Class $)$} \\
\cline { 2 - 4 } & $\mathrm{New}$ & Existing & $\mathrm{New}$ & Existing \\
\hline
\end{tabular}




\begin{tabular}{|c|c|c|c|c|}
\hline Austria & 160 & 200 & 170 & 250 \\
\hline \multirow{3}{*}{ Belgium } & $\begin{array}{l}45 \text { (Brussels } \\
\text { region) }\end{array}$ & \multirow{3}{*}{$\sim 54$} & $\begin{array}{c}(95-2.5) \\
*(\mathrm{~V} / \mathrm{S})(\text { Brussels } \\
\text { region) }\end{array}$ & \multirow{3}{*}{$\sim 108$} \\
\hline & $\begin{array}{l}30 \text { (Flemish } \\
\text { region) }\end{array}$ & & $\begin{array}{l}40 \text { (Flemish } \\
\text { region) }\end{array}$ & \\
\hline & $\begin{array}{l}60(\text { Walloon } \\
\text { region) }\end{array}$ & & $\begin{array}{l}60 \text { (Walloon } \\
\text { region) }\end{array}$ & \\
\hline Bulgaria & $\sim 30-50$ & $\begin{array}{l}\sim 40- \\
60\end{array}$ & $\sim 30-50$ & $\sim 40-60$ \\
\hline Cyprus & 100 & 100 & 125 & 125 \\
\hline $\begin{array}{l}\text { Czech } \\
\text { Republic }\end{array}$ & 75\%-80\% PE & $\begin{array}{r}75 \%- \\
80 \% \mathrm{PE} \\
\end{array}$ & $90 \% \mathrm{PE}$ & $\begin{array}{l}90 \% \\
\mathrm{PE}\end{array}$ \\
\hline Germany & $40 \% \mathrm{PE}$ & $\begin{array}{l}55 \% \\
\mathrm{PE}\end{array}$ & $\mathrm{n} / \mathrm{a}$ & $\mathrm{n} / \mathrm{a}$ \\
\hline Denmark & 20 & 20 & 25 & 25 \\
\hline \multirow{7}{*}{ Estonia } & \multirow{4}{*}{$\begin{array}{l}50 \text { (detached } \\
\text { house) }\end{array}$} & $\mathrm{n} / \mathrm{a}$ & $\begin{array}{l}100 \text { (office } \\
\text { buildings) }\end{array}$ & $\mathrm{n} / \mathrm{a}$ \\
\hline & & $\mathrm{n} / \mathrm{a}$ & $\begin{array}{l}130 \text { (hotels, } \\
\text { restaurants) }\end{array}$ & $\mathrm{n} / \mathrm{a}$ \\
\hline & & $\mathrm{n} / \mathrm{a}$ & $\begin{array}{l}120 \text { (public } \\
\text { buildings) }\end{array}$ & $\mathrm{n} / \mathrm{a}$ \\
\hline & & $\mathrm{n} / \mathrm{a}$ & $\begin{array}{l}130 \text { (shopping } \\
\text { malls) }\end{array}$ & $\mathrm{n} / \mathrm{a}$ \\
\hline & \multirow{3}{*}{$\begin{array}{l}100 \text { (apartment } \\
\text { blocks) }\end{array}$} & $\mathrm{n} / \mathrm{a}$ & 90 (schools) & $\mathrm{n} / \mathrm{a}$ \\
\hline & & $\mathrm{n} / \mathrm{a}$ & $\begin{array}{l}100 \text { (day care } \\
\text { centres) }\end{array}$ & $\mathrm{n} / \mathrm{a}$ \\
\hline & & $\mathrm{n} / \mathrm{a}$ & 270 (hospitals) & $\mathrm{n} / \mathrm{a}$ \\
\hline \multirow{2}{*}{ France } & \multirow{2}{*}{$40-65$} & 80 & $\begin{array}{c}70 \text { (offices } \\
\text { without AC) }\end{array}$ & $\begin{array}{l}60 \% \\
\mathrm{PE}\end{array}$ \\
\hline & & $\mathrm{n} / \mathrm{a}$ & $\begin{array}{l}110 \text { (offices } \\
\text { with AC) }\end{array}$ & $\mathrm{n} / \mathrm{a}$ \\
\hline Croatia & $33-41$ & $\mathrm{n} / \mathrm{a}$ & $\mathrm{n} / \mathrm{a}$ & $\mathrm{n} / \mathrm{a}$ \\
\hline Hungary & $50-72$ & $\mathrm{n} / \mathrm{a}$ & $60-115$ & $\mathrm{n} / \mathrm{a}$ \\
\hline Ireland & 45 (Energy load) & $\begin{array}{l}75- \\
150 \\
\end{array}$ & $\sim 60 \% \mathrm{PE}$ & $\mathrm{n} / \mathrm{a}$ \\
\hline Italy & Class A1 & $\begin{array}{l}\text { Class } \\
\text { A1 }\end{array}$ & Class A1 & $\begin{array}{l}\text { Class } \\
\text { A1 }\end{array}$ \\
\hline Latvia & 95 & 95 & 95 & 95 \\
\hline $\begin{array}{l}\text { Lithuani } \\
\text { a }\end{array}$ & Class A++ & $\begin{array}{l}\text { Class } \\
\mathrm{A}++\end{array}$ & Class $\mathrm{A}++$ & $\begin{array}{l}\text { Class } \\
\mathrm{A}++\end{array}$ \\
\hline $\begin{array}{l}\text { Luxemb } \\
\text { urg }\end{array}$ & Class AAA & $\mathrm{n} / \mathrm{a}$ & Class AAA & $\mathrm{n} / \mathrm{a}$ \\
\hline Malta & 40 & $\mathrm{n} / \mathrm{a}$ & 60 & $\mathrm{n} / \mathrm{a}$ \\
\hline $\begin{array}{l}\text { Netherla } \\
\text { nds }\end{array}$ & 0 & $\mathrm{n} / \mathrm{a}$ & 0 & $\mathrm{n} / \mathrm{a}$ \\
\hline Poland & $60-75$ & $\mathrm{n} / \mathrm{a}$ & 45-70-190 & $\mathrm{n} / \mathrm{a}$ \\
\hline Romania & $93-217$ & $\mathrm{n} / \mathrm{a}$ & 50-192 & $\mathrm{n} / \mathrm{a}$ \\
\hline Spain & Class A & $\mathrm{n} / \mathrm{a}$ & Class A & $\mathrm{n} / \mathrm{a}$ \\
\hline
\end{tabular}




\begin{tabular}{ccccc}
\hline Sweden & $30-75$ & n/a & $30-105$ & n/a \\
\hline Slovenia & $45-50$ & $70-90$ & 70 & 100 \\
\hline \multirow{2}{*}{ Slovakia } & $\begin{array}{c}32 \text { (apartment } \\
\text { buildings) }\end{array}$ & n/a & $60-96$ (offices) & n/a \\
\cline { 2 - 5 } & $\begin{array}{c}54 \text { (family } \\
\text { houses) }\end{array}$ & n/a & 34 (schools) & n/a \\
\hline UK & $\sim 44$ & n/a & n/a & n/a \\
\hline
\end{tabular}

The establishment of numeric benchmarks for NZEBs primary energy use indicators is most useful when the values to be compared result from homogeneous calculations. The values suggested for NZEBs projecting the 2020 prices and technologies, benchmarks for the energy performance are in the reported in Table 3 for the different climatic zones.

Table 3: NZEBs level of performance $\left(\mathrm{kWh} / \mathrm{m}^{2} \mathrm{y}\right)$ per building type according to the European climate. Derived from [27].

\begin{tabular}{|c|c|c|c|c|}
\hline & \multicolumn{4}{|c|}{ Climate } \\
\hline Building type & $\begin{array}{l}\text { Mediterranean } \\
\text { Catania (others: } \\
\text { Athens, Larnaca, } \\
\text { Luga, Seville, } \\
\text { Palermo) }\end{array}$ & $\begin{array}{l}\text { Oceanic } \\
\text { Paris (others: } \\
\text { Amsterdam, Berlin, } \\
\text { Brussels, } \\
\text { Copenhagen, Dublin, } \\
\text { London, Macon, } \\
\text { Nancy, Prague, } \\
\text { Warszawa) }\end{array}$ & $\begin{array}{l}\text { Continental } \\
\text { Budapest (others: } \\
\text { Bratislava, } \\
\text { Ljubljana, Milan, } \\
\text { Vienna) }\end{array}$ & $\begin{array}{l}\text { Nordic } \\
\text { Stockholm (others: } \\
\text { Helsinki, Riga, } \\
\text { Stockholm, } \\
\text { Gdansk, Tovarene) }\end{array}$ \\
\hline & \multicolumn{4}{|c|}{ Level of performance $\left(\mathrm{kWh} / \mathrm{m}^{2} \mathrm{y}\right)$} \\
\hline \multicolumn{5}{|l|}{$\begin{array}{l}\text { Office } \\
\text { buildings }\end{array}$} \\
\hline $\begin{array}{l}\text { net primary } \\
\text { energy }\end{array}$ & $20-30$ & $40-55$ & $40-55$ & $55-70$ \\
\hline use primary energy & $80-90$ & $85-100$ & $85-100$ & $85-100$ \\
\hline \begin{tabular}{|l} 
on-site RES \\
sources
\end{tabular} & 60 & 45 & 45 & 30 \\
\hline $\begin{array}{c}\text { New single } \\
\text { family house }\end{array}$ & & & & \\
\hline
\end{tabular}




\begin{tabular}{|c|c|c|c|c|}
\hline $\begin{array}{c}\text { net primary } \\
\text { energy }\end{array}$ & $0-15$ & $15-30$ & $20-40$ & $40-65$ \\
\hline $\begin{array}{c}\text { primary energy } \\
\text { use }\end{array}$ & $50-65$ & $50-65$ & $50-70$ & $65-90$ \\
\hline $\begin{array}{c}\text { on-site RES } \\
\text { sources }\end{array}$ & 50 & 35 & 30 & 25 \\
\hline
\end{tabular}

The analysis on the progress of NZEBs definition implementation in Europe revealed that:

- The main included energy uses are: heating, domestic hot water (DHW), ventilation, and cooling. Auxiliary energy and lighting are taken into account in almost all Member States. Several Member States also include appliances and central services.

- The most common choice regarding the energy balance calculation is the difference between the primary energy demand and the energy generated, over a period one year, and considering annual constant weightings/factors (e.g. primary energy factors).

- Single building or building unit are the most frequent indicated physical boundary for the calculation, but the differences among building unit/site/zone/part need to be better addressed.

- As regards the normalization factors, conditioned area is the most agreed upon choice in Member States. Although other options, such as net floor area and treated floor are selected.

- The most common considered RES option is the on-site generation, but many countries also consider external generation and nearby generation.

Member States indicate the application of low energy building technologies and available RES. The most used technologies are PV, solar thermal, air- and ground-source heat pumps, geothermal, passive solar, passive cooling, wind power, biomass, biofuel, micro CHP, and heat recovery.

The current situation towards the establishment of applied national NZEBs definitions has improved in Europe in comparison with the previous report [47]. Table 4 reports a qualitative evaluation of the current status of NZEBs development in Member States [48].

Table 4: Evaluation of the NZEBs development in Europe ( $\checkmark$ =satisfactory development, / = partial development $\mathrm{X}=$ not defined/unclear). Source[17].

\begin{tabular}{|l|c|c|c|c|}
\hline Country & $\begin{array}{c}\text { NZEB } \\
\text { Definition }\end{array}$ & $\begin{array}{c}\text { RES included in } \\
\text { the NZEB } \\
\text { concept }\end{array}$ & $\begin{array}{c}\text { Qualitative and } \\
\text { quantitative } \\
\text { intermediate } \\
\text { targets }\end{array}$ & $\begin{array}{c}\text { Measures } \\
\text { promoting deep } \\
\text { or NZEB } \\
\text { renovation }\end{array}$ \\
\hline Austria & $\checkmark$ & $\checkmark$ & $/$ & $/$ \\
\hline
\end{tabular}




\begin{tabular}{|c|c|c|c|c|}
\hline Belgium - Brussels & $\checkmark$ & l & 1 & $\checkmark$ \\
\hline Belgium - Flanders & $\checkmark$ & l & 1 & $\checkmark$ \\
\hline Belgium - Wallonia & $\checkmark$ & 1 & 1 & $\checkmark$ \\
\hline Bulgaria & 1 & 1 & 1 & 1 \\
\hline Cyprus & $\checkmark$ & $\checkmark$ & $\mathrm{X}$ & 1 \\
\hline Czech Republic & $\checkmark$ & $\checkmark$ & 1 & $\checkmark$ \\
\hline Germany & 1 & 1 & 1 & $\checkmark$ \\
\hline Denmark & $\checkmark$ & $\checkmark$ & 1 & $\checkmark$ \\
\hline Estonia & $\checkmark$ & $\checkmark$ & $\mathrm{X}$ & 1 \\
\hline Greece & $\mathrm{X}$ & $\mathrm{X}$ & $\mathrm{X}$ & 1 \\
\hline Spain & $\mathrm{X}$ & $\mathrm{X}$ & $\mathrm{X}$ & 1 \\
\hline Finland & 1 & $\mathrm{X}$ & $\mathrm{X}$ & $\checkmark$ \\
\hline France & $\checkmark$ & $\checkmark$ & $\checkmark$ & $\checkmark$ \\
\hline Croatia & $\checkmark$ & 1 & 1 & 1 \\
\hline Hungary & 1 & $\checkmark$ & $\mathrm{X}$ & 1 \\
\hline Ireland & $\checkmark$ & $\checkmark$ & 1 & $\checkmark$ \\
\hline Italy & $\checkmark$ & & 1 & I \\
\hline Latvia & $\checkmark$ & $\checkmark$ & $\mathrm{X}$ & 1 \\
\hline Lithuania & $\checkmark$ & $\checkmark$ & 1 & 1 \\
\hline Luxembourg & $\checkmark$ & $\checkmark$ & 1 & $\checkmark$ \\
\hline Malta & $\checkmark$ & I & 1 & $\checkmark$ \\
\hline Netherlands & $\checkmark$ & $\checkmark$ & $\checkmark$ & $\checkmark$ \\
\hline Poland & $\checkmark$ & 1 & 1 & $\sqrt{ }$ \\
\hline Portugal & 1 & $\mathrm{X}$ & 1 & $\mathrm{X}$ \\
\hline Romania & $\checkmark$ & $\checkmark$ & 1 & $\sqrt{ }$ \\
\hline Slovenia & $\checkmark$ & $\checkmark$ & $\sqrt{ }$ & 1 \\
\hline Slovakia & $\checkmark$ & $\checkmark$ & 1 & 1 \\
\hline Sweden & 1 & $\mathrm{X}$ & $\mathrm{X}$ & $\sqrt{ }$ \\
\hline United Kingdom & 1 & $\mathrm{X}$ & 1 & $\sqrt{ }$ \\
\hline
\end{tabular}

Different system boundaries and energy uses are the cause of high variations within the described definitions. The level of energy efficiency, the inclusion of lighting and appliances, as well as the recommended renewables to be implemented vary across Europe.

The requirements of primary energy show a significant variability and reflect different national and regional calculation methodologies and energy flows. National energy policies have evolved with new legislation and methodologies introduced with technical regulatory measures to improve the energy efficiency of buildings and RES generation.

The reduction of energy demand through energy efficient measures and the utilization of RES to supply the remaining demand have reached common agreement towards the implementation of the NZEBs concept.

In relation intermediate targets for improving the energy performance of new buildings, most Member States presented only qualitative targets. These appear extremely variable, and 
the quantitative targets are almost never defined. Reaching the NZEBs target in new buildings appears to be feasible according to design studies [49] and studies on energy performance optimization [50] [51]. The challenge of achieving energy efficiency targets in Europe remains for existing buildings. The current renovation rate is low due to the economic crisis which started in 2007. In 2011, the renovation rate of the European building stock has been assessed between 0.5\% and 2.5\% per year [52]. Buildings dating between 1945 and 1980 have the largest energy demand. Moreover, the existing stock is characterised by a high heterogeneity in terms of uses, climatic areas, construction traditions and different system technologies [53].

\section{Discussion on definitions}

\subsection{US DOE ZEB and positive energy building definitions}

In terms of source energy balance, the DOE ZEB definition is then:

$E_{\text {source }}=\sum_{i}\left(E_{\text {del }, i} \cdot r_{\text {del }, i}\right)-\sum_{i}\left(E_{\text {exp }, i} \cdot r_{\text {exp }, i}\right) \leq 0$

$E_{d e l, i}$ is the delivered energy for energy type $i$;

$E_{\text {exp }, i}$ is the exported on-site renewable energy for energy type $i$;

$r_{d e l, i}$, is the source energy conversion factor for the delivered energy type $i$;

$r_{\text {exp, } i}$ is the source energy conversion factor for the exported energy type $i$.

In relation to the EU definition of NZEB, as reported in Article 2, and Article 9 [14], using the CEN standard developed for the EPBD, both the old EN 15603 [44] or the new EN/ISO 52000-1 [41], to assess the buildings energy performance, the corresponding primary energy use is calculated as:

$E_{p}=\sum_{i}\left(E_{d e l, i} \cdot f_{p, d e l, i}\right)-\sum_{i}\left(E_{e x p, i} \cdot f_{e p, x p, j}\right)$

where:

$E_{d e l, i}$ is the delivered energy for energy carrier $i$;

$E_{\text {exp,i }}$ is the exported energy for energy carrier $j$;

$f_{d e l, i}$ is the primary energy factor for the delivered energy carrier $i$;

$f_{\text {exp }, i}$ is the primary energy factor for the exported energy carrier $j$.

Then, before 2019, each Member State has to set up the maximum value allowed for the NZEB of the numerical indicator of primary energy use in $\mathrm{kWh} / \mathrm{m}^{2} \mathrm{y}$. After that, if $A$ is a specified building area (useful, gross, etc.), the EU NZEB is defined as:

$$
E P_{P}=\frac{E_{P}}{A} \leq E P_{\max }^{N Z E B}=\max \left[\frac{E_{p}}{A}\right]_{N Z E B}
$$


where the upper limiting value shall be fixed using the cost optimality procedure described in [18].

Thus, a building that complies with the DOE ZEB definition (1) may be also an EU NZEB, while a building that complies with the EU NZEB (3) could not be a DOE ZEB. The fist statement will be clarified later, while the second is evident.

The first issue can be identified in the loss of clarity and unicity when using (1) in association with Zero or Net Zero terms. US DOE changed back the term NZEB to ZEB because the term Net was unclear to the customers. However, this does not take into account that something that mostly can be less than zero is called zero. This is just against the common customer understanding of zero.

Following this statement, a second issue is immediately coming out when we try to define a Positive Energy Building (PEB), i.e. a building that use less delivered energy than exported on-site renewable energy. This would mean that its source energy is negative in contrast with the common customer sense for which positive means greater than zero. In addition, it is common to seemingly perceive that a ZEB or a PEB can create energy, violating the energy conservation principle. This could be misread by users that could waste energy believing that, coming from renewable sources, energy is free of costs. The main issue is that this approach is not really able to assess the building energy performance quality. It is a common understanding that a valid energy intensity quality index has always to be able to distinguish between buildings that do not have the same quality. It is possible to demonstrate that source energy, as calculated according to (1), with the same source energy conversion factors for both delivered and exported energy, from renewable or non-renewable energy sources, is not always able to do that.

As example, we can consider a full electric ZEB, as in the first example in [28], which has an actual annual delivered energy of $88,000 \mathrm{kWh}$ and on-site renewable exported energy of 94,000 kWh electricity from photovoltaics, and if we assume that the heating system is just made of direct electric heaters. Using (1) with the same ASHRAE source energy conversion factors of 3.15 for electricity, the source energy is:

$$
E_{\text {source }}=94,000 \cdot 3.15-88,000 \cdot 3,15=-18,900<0
$$

Thus, this building is a DOE ZEB or a Positive Energy Building.

We now consider exactly the same building with the same loads, but with water heaters supplied by a water-to-water electric heat pump. In this case, if we leave the same PV field, the same overall electrical energy production, but we use a heat pump to cover the same thermal loads, the electricity consumption for heating will be much lower. Thus, we resize 
the PV field in a way to maintain the same electrical energy difference between delivered and exported, i.e. 6,000 kWh. Assuming the actual annual delivered energy of 48,000 $\mathrm{kWh}$ and on-site renewable exported energy of 54,000 kWh electricity from photovoltaics, the source energy is still the same as before. As a consequence, we can argue that this method is non able to distinguish between different heat generation systems attributing the same performance index (the source energy in this case) to the building with the heat pump and to that with direct electric heaters. A second weak point is that these two "equivalent cases" are not equivalent from the electric grid fuel use point of view. This is because, balancing the import-export at the site boundary, the highest loss experienced by the grid is not taken into consideration when carrying up and down more energy for the same net production from renewable energy sources.

This issue is mainly due to the use of the same source energy conversion factors for both the grid electricity and the on- site renewable exported electricity, i.e. the so-called substitution value approach.

If the aim is to transform the way in which the building uses energy and to achieve a rational and optimal use of all energy sources, this approach might fail because it gives more importance to the net renewable energy delivered to the grid than to lower the building energy needs and to increase on-site generation system efficiencies. In fact, if the economic cost is not an issue, a building with the double energy need in comparison with another can have the same negative value of the source energy just using two times or more energy produced by renewable energy sources.

\subsection{NZEB definition}

The most important question with the NZEB definition relates the metric and the primary energy to be used in the performance indicator. As it is not specified, the total, non-renewable or renewable primary energy may be used. A simple reasoning can help to select the most compatible with the given NZEB definition.

The starting point is the NZEB definition that is not a Net Zero Energy Building for two main reasons. The first is that Net ZEB does not comply with the given NZEB definition because it is possible to have Net ZEBs, which do not respect the request of "very low amount of energy required” which "should be covered to a very significant extent by energy from renewable sources”. It is quite evident that a building can be a Net ZEB having a high amount of energy required partially covered by a high amount of non-renewable delivered energy, if it is overproducing energy carriers from renewable energy sources and exports 
them. The second is more general and is related to the metric used to define the zero. This should not depend on local conditions, otherwise the zero in not unique. It is evident that if (2) has to be zero, the only way to be compatible with any positive value of the primary energy factors (which are locally dependent according to the EPBD definition) is that all the delivered and exported energy carriers have to be zero, i.e.:

$$
\begin{aligned}
& E_{P}=\sum_{i}\left(E_{d e l, i} \cdot f_{P, d e l, i}\right)-\sum_{i}\left(E_{\text {exp }, j} \cdot f_{P, \text { exp }, J}\right)=0 \forall f_{P, d e l, i}>0 ; \forall f_{P, \text { exp }, j}>0 \\
& \Rightarrow E_{d e l, i}=0 \forall i ; E_{\text {exp }, j}=0 \forall j
\end{aligned}
$$

However, this is the definition of the off-grid or Autonomous ZEB. Thus, the reference zero for the EU NZEB is the Autonomous ZEB. Once we have the zero, the nearly ZEB performance indicator is consistent with EU NZEB definition if it is able to approach to such zero. If the total primary energy (i.e.. non-renewable plus renewable) is used and if the energy conservation principle is respected, it is evident that, as a building is a net energy consumer (it is just destroying exergy or creating entropy dissipating high value energy to the environment at lower value), this performance index can never reach zero, neither in an ideal case. The use of renewable primary energy is not appropriate considering the goal of $\mathrm{CO}_{2}$ reductions. This implies that the only possible consistent primary energy is the nonrenewable one. Despite of that, EN ISO/DIS 52000-1:2017 [41] is suggesting to use the total. The total primary energy may be used, but not in the actual context. If we remark that energy saving has also to be applied to the renewable energy sources, the displayed goal has to be changed. Future policy updates may refer to low or very low energy building, because we can never reach zero if we use total primary energy to qualify the performance. Such choice also reflects the market point of view: net ZEB and Positive Energy Building do not exist any longer if total primary energy is used. The total primary energy supporters argue that, using such quantity to set up the minimum performance limits, it avoids an excessive use of on-site renewable energy sources to balance high building needs instead of reducing them before to use renewable energies. It is easy to show that economic issues drive for energy savings through optimised envelope design before to use renewable energy to feed the building services systems. Thus, a very low limit on non-renewable primary energy can be economically archived only if the building energy needs have been reduced as much as economically feasible.

This result has a strong implication on the primary energy conversion factors, which must only be referred to non-renewable primary energy. This is compatible with the general 
goal of EPBD, the $\mathrm{CO}_{2}$ emission reduction, related to the non-renewable energy use through combustion processes.

\subsection{Primary energy conversion factors}

In compliance with the EPBD NZEB definition, the conversion factors must be applied only to non-renewable energy carriers (i.e. produced by non-renewable energy sources) to account for non-renewable energy sources. The other issues are: how to calculate their values and if the substitution value approach is consistent with the EU NZEB definition.

The first is not a real issue as the superseded EN 15603:2008 and EN ISO/DIS 520001:2015 are quite clear about the meaning of such coefficient and the definition allows an unambiguous determination. They are only applied to energy carriers delivered or exported out of the site boundary to quantify how much of related primary energy has been used to produce and deliver such energy carrier. This determination could be difficult to be achieved, but it possible refer to the standard thermodynamics calculation. Of course the time variability of the losses chain from the source to the user may require updating their values on a short time base (the same as the energy performance calculation time base, from one hour to one year), but statistical analysis of specific energy carriers may help providing the most probable time profile. A conventional time profile for time variant primary energy conversion factor is acceptable considering that the EPDB performance index for NZEB is conventional and is the chosen way to push for having more performant buildings on the market.

In relation to the substitution value approach (to use the same conversion factors of the non-renewable deliver energy carrier for the renewable exported energy carrier), we have shown in the previous section that such approach does not allow to distinguish between different on-site generation systems which realize the same net energy exchange (no matter positive or negative). Thus, it must be avoided using zero for the on-site renewable energy carriers exported outside the site boundary.

However, such approach does not match with the net zero concept applied to primary energy, which aims to valorise the distributed green electricity generation. As a consequence, it becomes crucial to valorise the building that participates to the substitution of $\mathrm{CO}_{2}$ based power generation, feeding the grid with $\mathrm{CO}_{2}$ free electricity, when the net ZEB concept has to be abandoned.

\subsection{Alternative to the Net ZEB to account for the renewable energy export}


From the previous sections, it would seem that the given interpretation of the definition NZEB may penalize those buildings that produce energy carriers with the exploitation of renewable energy sources on site, and that may export the overproduction contributing to the increase of the renewable energy used by the country. This is a non-issue if it is recognised that the EPBD performance indicator qualifies only the energy self-sustainability of a building. Furthermore, the building's capacity to contribute to the production of zero $\mathrm{CO}_{2}$ energy carriers for the benefit of the national energy system is another issue. Both aspects are important but do not need to be represented by a single index, which would take away clarity by mixing together such different objectives.

There is an additional motivation that should push to keep these aspects separate, besides the fact that the first is a property only of the building, while the second is a combined property of the building and of the energy system that it is connected to. A unique building property should not be confused with a combined property of the building and the energy system, which it is interconnected with. Among other things, the aspects related to the issue of permission release and verification also motivate this differentiation. In fact, the building energy performance assessment and verification is usually in the responsibility of municipalities and real estate owners, in the sense that the related documentation is associated with the building permit and sales contracts and that performance verification is handled at a community level. Instead, the exchange of energy carriers between power producers and users, today limited to the electric energy carrier, is in the hand of the electric grid Authority. The Grid Authority has then the need to manage local productions in order to avoid the collapse of the network to overload and excessive imbalances. Ultimately, it is more efficient to separate the two features, introducing alongside the primary energy need, which defines the energy performance index, another index, which uniquely defines the building contribution to the regional/national zero $\mathrm{CO}_{2}$ electric energy production. This "production" index must be under the Grid Authority control that in relation with the local grid capacity may encourage or discourage this production in specific areas. In particular, having the objective of the reduction of $\mathrm{CO}_{2}$ production, not only this separation allows supporting and improving the exploitation of photovoltaic electricity, but also that produced by on-site cogeneration systems and exported to the grid. In the latter case, if for instance the building primary energy use is attributed only to the heating/cooling service, there is no primary energy consumption allocated to the exported cogenerated electricity and hence no $\mathrm{CO}_{2}$ production. 
It is then possible to define the index of contribution to the production of electricity from renewable energy or "CO 2 -free" generators as the $\mathrm{CO}_{2}$ Neutral Exported Electrical Energy Index (NEEE). It can be defined as the share of export of $\mathrm{CO}_{2}$ neutral electricity building production from renewable energy sources and from cogeneration systems per unit of useful area of the building, as:

$$
N E E E=\left[\sum_{R E S=1}^{N}\left(W_{R E S, r e n, \exp }\right)+W_{C H P, \exp }\right] / A
$$

where

- $\mathrm{W}_{\mathrm{RES}, \text { ren,exp }}$ share of export of CO2 neutral electricity building production from renewable energy sources exploited on-site;

- $\mathrm{W}_{\mathrm{CHP} \text {,exp }}$ share of export of $\mathrm{CO}_{2}$ neutral electricity building production from thermal driven building cogeneration systems or the relative index. This is defined as the percentage of $\mathrm{CO}_{2}$ Neutral Exported Electrical Energy per Primary Energy Need (NEEE\%): the yearly amount of $\mathrm{CO}_{2}$ neutral exported electrical energy to the grid and the overall yearly primary energy use of the building. This is:

$$
N E E E \%=\frac{N E E E}{E P} \cdot 100=\left\{\left[\sum_{R E S=1}^{N}\left(W_{R E S, \text { ren,exp }}\right)+W_{C H P, \exp }\right] / E_{p}\right\} \cdot 100
$$

These two indices can be used to define incentives for buildings, which make a positive contribution to the national electric grid with $\mathrm{CO}_{2}$ free electricity, regardless their primary energy index (i.e. if they are low or high energy buildings).

\section{Conclusions}

Improving energy efficiency in buildings represents a great opportunity to decrease energy consumptions and increase renewable production. Buildings are the core of the European 2020 and 2030 strategies of climate and energy targets. The building sector can contribute to mitigate climate change and at the same time delivering many other benefits, such as a decrease of gas imports, related costs, and improvement of energy security.

Starting from the overall trends related to energy consumption in residential and nonresidential buildings, this paper outlines the European policy framework on buildings. The paper then focus on nearly zero energy buildings (NZEBs) highlighting the main NZEBs definitions, issues and status of implementation in European countries.

The analysis has shown how the NZEB topic has gained a growing attention and how the NZEB implementation is progressing in Europe. 
However, many issues have to be considered in future policies. The European countries have to further adopt specific actions to exploit the potential energy savings deriving from the building sector.

To overcome some of the underlined issues and to clarify what NZEBs mean in the EPBD perspective, the following widely agreed statements should be considered:

a) thermal and electric energy need reduced as much as reasonably possible (insulation, daylighting, thermal mass activation, etc.);

b) service systems energy need reduced as much as economically feasible (heat recovery systems, increased efficiency of components and subsystems, etc.);

c) building thermal and electrical energy use covered to a significant extent with the use of energy carriers produced on-site or nearby from renewable sources (solar thermal and PV systems, heat pumps, etc.);

d) the provisions of points $\mathrm{A}, \mathrm{B}$ and $\mathrm{C}$ must be obtained under the economic and/or financial sustainability (to comply with the cost-optimality concept);

e) the ability to be a distributed producer of $\mathrm{CO}_{2}$ neutral electricity for the network is not a NZEB requirement, but it can nonetheless be exploited separately with an appropriate index.

Following such statements some aspects could be further clarified in the NZEB definition as follows:

- The nearly zero or very low amount of energy is related to the required energy use that should be obtained reducing as much as possible the energy need, compatibly with the use of building and ensuring the comfort and air quality, increasing as much as feasible the service systems efficiencies;

- the numerical indicator refers to the non-renewable primary energy use expressed in $\mathrm{kWh} / \mathrm{m}^{2} \mathrm{y}$;

- the primary energy factors for the determination of the non-renewable primary energy use may be based on national or regional yearly average values and may take into account relevant European standards.

The interdisciplinary nature of the NZEB concept needs further cooperation among all the actors involved in the area. The linked economic sector has already begun to involve architects, engineers, researchers dealing with building physics, economists, environmental analysts, and policy makers. It is foreseeable that the NZEB implementation can further stimulate industrial competitiveness and increase asset values through rental and sales premiums. 


\section{References}

[1]Eurostat. Final energy consumption by sector. 2014. Available at: http://epp. eurostat.ec.europa.eu/portal/page/portal/statistics/search/database.

[2]Green Paper, A 2030 framework for climate and energy policies, COM (2013)169 http://ec.europa.eu/energy/consultations/20130702 green paper 2030en.htm European Commission. 2014. Taking stock of the Europe 2020 strategy for smart sustainable and inclusive growth, Brussels, 19/3/2014.

[3] Odyssee-Mure database, available at: http://www.odyssee-mure.eu/

[4]Eurostat, European System of Accounts - ESA 1995, Office for Official Publications of the European Communities, Luxembourg, 1996.

[5]European Commission. 2014. Taking stock of the Europe 2020 strategy for smart, sustainable and inclusive growth”, Brussels, 19/3/2014.

[6]Shady Attia, Polyvios Eleftheriou, Flouris Xeni, Rodolphe Morlot,Christophe Ménézo, Vasilis Kostopoulos, Maria Betsi ,Iakovos Kalaitzoglou, Lorenzo Pagliano, Maurizio Cellura, Manuela Almeida, Marco Ferreira, Tudor Baracu, Viorel Badescu, Ruxandra Crutescu, Juan Maria Hidalgo-Betanzos, Overview and future challenges of nearly zero energy buildings(nZEB) design in Southern Europe, Energy and Buildings 155 (2017) 439-458.

[7]D'Agostino D. 2015. Assessment of the progress towards the establishment of definitions of Nearly Zero Energy Buildings (nZEBs) in European Member States, Journal of Building Engineering (2015), http://dx.doi.org/10.1016/j.jobe.2015.

[8]BPIE, Europe's buildings under the microscope - 2011.

[9]Delia D'Agostino, Paolo Zangheri, Luca Castellazzi, Towards Nearly Zero Energy buildings (NZEBs) in Europe: a focus on retrofit in non-residential buildings, Energies, 2017, 10, 117; doi:10.3390/en10010117.

[10] ODYSSEE - MURE, Energy Efficiency Trends and Policies in the Household and Tertiary Sectors, An Analysis Based on the ODYSSEE and MURE Databases, 2015, available at: http://www.odyssee-mure.eu/publications/br/energy-efficiency-in-buildings.html

[11] Delia D’Agostino, Barbara Cuniberti, Paolo Bertoldi, Energy consumption and efficiency technology measures in European non-residential buildings European, Energy and Buildings 153 (2017) 72-86, http://dx.doi.org/10.1016/j.enbuild.2017.07.062

[12] Delia D’Agostino, Barbara Cuniberti, Paolo Bertoldi, Data on European nonresidential buildings, Data in Brief 14 (2017) 759-762, http://dx.doi.org/10.1016/j.dib.2017.08.043

[13] EU, Directive 2002/91/EC. European Parliament and of the Council of 16 December 2002 on the Energy Performance of Buildings, Official Journal of the European Communities (2003): 65-71.

[14] EU, Directive 2012/27/EU. European Parliament and of the Council of 25 October 2012 on energy efficiency, amending Directives 2009/125/EC and 2010/30/EU and repealing Directives 2004/8/EC and 2006/32/EC.

[15] EU, Guidelines accompanying Commission Delegated Regulation (EU) No 244/2012 of 16 January 2012 supplementing Directive 2010/31/EU of the European Parliament and of the Council. Official Journal of the European Union.

[16] D'Agostino, D., et al., Synthesis Report on the National Plans for NZEBs; EUR 27804 EN; doi 10.2790/659611.availbale at: http://publications.jrc.ec.europa.eu/repository/bitstream/JRC97408/reqno_jrc97408_online\% 20nzeb\%20report(1).pdf 
[17] EU, Directive 2010/31/EU. European Parliament and of the Council of 19 May 2010 on the Energy Performance of Buildings (recast), Official Journal of the European Union (2010): 13-35.

[18] EU, 244/2012. Commission Delegated Regulation No244/2012 of 16 January 2012. Supplementing Directive 2010/31/EU of the European Parliament and of the Council on the energy Performance of Buildings by Establishing a Comparative Methodology Framework for Calculating Cost-optimal Levels of Minimum Energy Performance Requirements for Buildings and Building Elements. Official Journal of the European Union.

[19] Congedo, P.M.; Baglivo, C.; D'Agostino, D.; Zacà, I. Cost-optimal design for nearly zero energy office buildings located in warm climates. Energy, 2015, 91, 967-982.

[20] Zacà, I.; D’Agostino, D.; Congedo, P.M.; Baglivo, C.; Assessment of costoptimality and technical solutions in high performance multi-residential buildings in the Mediterranean area, Energy Build. 2015, 102, 250-265.

[21] Ilaria Zaca, Delia D'Agostino, Paolo Maria Congedo, Cristina Baglivo, Data of cost-optimality and technical solutions for high energy performance buildings in warm climate. Data Brief. DOI: 10.1016/j.dib.2015.05.015.

[22] Baglivo, C.; Congedo, P.M.; D'Agostino, D.; Zacà, I Cost-optimal analysis and technical comparison between standard and high efficient mono-residential buildings in a warm climate, Energy 83 (2015) 560-575.

[23] Congedo, P.M.; Baglivo, C.; D'Agostino, D.; Tornese, G., Zacà, I., Efficient solutions and cost-optimal analysis for existing school buildings, Enegies, Energies 2016, 9(10), 851; doi:10.3390/en9100851.

[24] BPIE (Buildings Performance Institute Europe). Implementing the costoptimal methodology in EU countries. Pages 1-82. ISBN 9789491143083. http://bpie.eu/costoptimalmethodology.html

[25] Annunziata, E., Frey, M., \& Rizzi, F. Towards nearly zero-energy buildings: The state of art of national regulations in Europe. Energy (2013), 57, 125-133.

[26] CA EPBD, Concerted action EPBD: Implementing the energy performance of buildings directive (EPBD). Information of the joint initiative of EU Member States and the European Commission, Available at: http://www.epbd-ca.eu/themes/cost-optimum.

[27] EU, Commission Recommendation 2016/1318 of 29 July 2016 on Guidelines for the promotion of nearly zero-energy buildings and best practices to ensure that, by 2020, all new buildings are nearly zero-energy buildings.

[28] US Department of Energy. A Common Definition for Zero Energy Buildings. DOE/EE-1247 September 2015

[29] Livio Mazzarella. Near zero, zero and plus energy buildings: revised definitions, proceedings of Clima 2016.

[30] M. Panagiotidou, R. J. Fuller, Progress in ZEBs - A review of definitions, policies and construction activity, Energy Policy 62 (2013): 196-206, http://dx.doi.org/10.1016/j.enpol.2013.06.099i.

[31] H. Lund, A. Marszal, P. Heiselbergb, Zero energy buildings and mismatch compensation factors, Energy and Buildings, 43 (7) (2011): 1646-1654, 10.1016/j.enbuild.2011.03.006.

[32] P. Torcellini, S. Pless, M. Deru, D. Crawley, 2006, Zero Energy Buildings: A Critical Look at the Definition, National Renewable Energy Laboratory and Department of Energy, US.

[33] ASHRAE. ASHRAE Vision 2020. Producing Net Zero Energy Buildings. A Report from ASHRAE, Atlanta, GA, January 2008 
[34] Marszal A.J., Heiselberg P. Zero Energy Building definition - a literature review. technical report of subtask A. IEA SHC/ECBCS Task 40/Annex 52 - Towards Net Zero Energy Solar Buildings. Aalborg, Denmark (2011).

[35] Marszal, A. J., Heiselberg, P., Bourrelle, J. S., Musall, E., Voss, K., Sartori, I., \& Napolitano, A. Zero Energy Building - A Review of definitions and calculation methodologies. Energy and Buildings, 43(4) (2011), 971-979.

[36] Sartori I., Napolitano A., Voss K. Net zero energy buildins: A consistent definition framework. Energy and Buildings, 48 (2012), 220-232.

[37] Voss, K., Sartori, I., Lollini, R.. Nearly-zero, Net zero and Plus Energy Buildings How definitions \&regulations affect the solutions. The REHVA European HVAC Journal, 49(6) (2012), 23-27.

[38] J. Laustsen, Energy Efficiency Requirements in Building Codes, Energy Efficiency Policies for New Buildings, Organisation for Economic Co-operation and Development/International Energy Agency, Paris, France, 2008.

[39] Louise Wells, Behzad Rismanchi, Lu Aye, A review of Net Zero Energy Buildings with reflections on the Australian context, Energy and Buildings 158 (2018) 616628.

[40] European Commission. Mandate to CEN, CENELEC AND ETSI for elaboration and adoption of standards for a methodology calculating the integrated energy performance of buildings and promoting the energy efficiency of buildings, in accordance with the terms set in the recast of the Directive on the energy performance of buildings (2001/31/UE). M/480 EN, Brusseles, 14th December 2010, available at https://ec.europa.eu/energy/sites/ener/files/documents/2010_mandate_480_en.pdf

[41] CEN - rEN ISO/DIS 52000-1:2017 - Energy performance of buildings - Overarching

EPBD assessment - Part 1: General framework and procedures. (ISO 52000-1:2017),

European Committee for Standardization, Brussels, 2017-07.

[42] Kurnitski, J., Mazzarella, L. et alt. How to define nearly net zero energy buildings nZEB, REHVA Journal., Vol.48 issue 3 (2011), 6-12.

[43] Kurnitski, J., Mazzarella, L. et alt.. REHVA nZEB technical definition and system boundaries for nearly zero energy buildings, REHVA Technical Report n. 4, (2013) REHVA, Brussels

[44] CEN, EN 15603:2008 - Energy performance of buildings - Overall energy use and definition of energy ratings, European Committee for Standardization, (2008), Brussels

[45] Joseph Williams, Rachel Mitchell, Vesna Raicic, Marika Vellei, Graham Mustard, Amber Wismayer, Xunzhi Yin, Stephen Davey, Muzzamil Shakil, Yuanzhang Yang, Anna Parkin, David Coley, Less is more: A review of low energy standards and the urgent need for an international universal zero energy standard, Journal of Building Engineering, 6 (2016) 65-74

[46] Angeliki Kylili, Paris A. Fokaides, European smart cities: The role of zero energy buildings, Sustainable Cities and Society, Volume 15, July 2015, Pages 86-95.

[47] EC, European Commission, National plans for nearly zero-energy buildings (2013), available: http://ec.europa.eu/energy/efficiency/buildings/implementation_en.htm.

[48] D'Agostino Delia, Zangheri Paolo, Development of the NZEBs concept in Member States, EUR 28252 EN, doi:10.2788/278314.

[49] Lu, Y.; Wang, S.; Shan, K. Design optimization and optimal control of gridconnected and standalone nearly/net zero energy buildings. Appl. Energy 2015, 155, 463477.

[50] Paolo Maria Congedo, Cristina Baglivo, Ilaria Zacà, Delia D'Agostino, High Performance Solutions and Data For Nzebs Offices Located in Warm Climates, Data in Brief, 
Available online $13 \quad$ October 2015, ISSN 2352-3409, http://dx.doi.org/10.1016/j.dib.2015.09.041.

[51] M. Ferrara, E. Fabrizio, J. Virgone, M. Filippi, A simulation based optimization method for cost-optimal analysis, Energy and Buildings 2014, http://dx.doi.org/10.1016/j.enbuild.2014.08.031

[52] Buildings Performance Institute Europe (BPIE). Europe's Buildings under the Microscope. A Country-by-Country Review of the Energy Performance of Buildings; BPIE: Brussels, Belgium, 2011

[53] Zebra 2020. Nearly Zero Energy Building Strategy 2020—Strategies for a Nearly Zero-Energy Building Market Transition in the European Union. Available online: http://zebra2020.eu/website/wp-content/uploads/2014/08/ZEBRA2020_Strategies-fornZEB_07_LQ_single-pages-1.pdf 